https://doi.org/10.18778/1509-877X.2020.01.02

Katarzyna Knawa*

Konrad Stolarski**

\title{
HEDGing OF PRICE ELEMENTS - REgULATORY AND TAX CONSIDERATIONS
}

\begin{abstract}
Summary. Due to the fact that the market price of raw materials has indirect or even direct impact on goods and services' price, hedging of price elements play a key role in a successful business. The purpose of this article is to present available instruments to address or even eliminate raw material price level insecurity, in particular through the acquisition off financial instrument, like derivatives. The purpose of this article is also to present the theoretical tax implications of hedging of price elements, and to analyse cash flows as a price adjustment mechanism.
\end{abstract}

Keywords: MIFID2, hedging, derivatives, tax, financial supervision

1. INTRODUCTION

It is far from controversy to state that the market price of raw materials has an impact on that of practically all goods and services. The scale of such impact naturally varies, dependent of the character and segment

* Tax advisor, counsel at FinTaxLegal Długosz Stolarski, Radcowie Prawni Spółka Partnerska, e-mail: katarzyna.knawa@fintaxlegal.com

** Attorney-at-law, partner at FintaxLegal Długosz Stolarski, Radcowie Prawni Spółka Partnerska, e-mail: konrad.stolarski@fintaxlegal.com 
of business and can be both direct as well as indirect. By way of example a shift in oil barrel price can result in the same not only in relation to the price of products offered by refineries and manufacturers or producers of oil-derivative products, but also in relation to the price of intangibles. This is due to the fact that practically the whole global economy is tied to the availability of oil-related or dependent products or services, one way or the other. Crude oil has therefore practically always been a source of business insecurity, which increased even further along with the volatility triggered by the significant reduction in crude oil prices in the second half of $2014 .{ }^{1}$

Due to the 'universal' character of oil, its example is a rather irreplicable paneconomic price tying mechanism. Nevertheless the price of also other raw material is a pricing policy factor in many segments of the economy. The volatility of price of other commodities also influences costs of sales. In case of businesses where tangible raw material resources constitute an essential element for the delivery or production of the end product, the price at which the entrepreneur is able to acquire resources has a direct impact on the scale of profitability of the business as a whole. ${ }^{2}$ For these reasons, such entrepreneurs face obvious financial risks due to their high debt to equity ratio structure and the nature of the trade of raw materials. Such risk furthermore increases in line with other factors, e.g. the volume of the enterprise itself, length of contract or investment, time thereof and also the scale in which an entrepreneur is forced to rely on raw materials. In Poland for instance, during the pre-Euro $2012^{3}$ investment boom, the rapid increased market need for steel and other materials and the simultaneous high volatility of their prices caused extreme problems for entrepreneurs and were one of the reasons of a series of bankruptcies of construction companies engaged in the investment process. ${ }^{4}$ On the market of construction

1 See B. Łamasz, N. Iwaszczuk, Ol Ivashchuk, Selected Methods of Securing the Refining Sector Against Crude Oil Price Fluctuations, "International Journal of Management and Economics" 2018, no. 54(3), p. 198, https://doi.org/10.2478/ijme-2018-0020

2 See also H. Moheb-Alizadeh, R. Handfield, The Impact of Raw Materials Price Volatility on Cost of Goods Sold (COGS) for Product Manufacturing, "IEEE Transactions on Engineering Management" 2018, vol. 65, iss. 3, p. 1.

3 The 2012 UEFA European Football Championship, commonly referred to as UEFA Euro 2012 was the 14th European Championship for men's national football teams organized by UEFA in Poland and Ukraine.

${ }^{4}$ On that topic in the context of the construction of highways see J. Kaliński, "Kwartalnik Kolegium Ekonomiczno-Społecznego. Studia i Prace" 2013, no. 13, p. 160, https:// doi.org/10.33119/KKESSiP.2013.1.6 
projects and most other markets where access and price of raw materials play a key role, the most obvious way to address this risk is to introduce appropriate indemnification or remuneration adjustment clauses in the contract. The downside of this mechanism is however that the possibility of introduction of such provisions is vastly dependent of the bargaining power of the particular contract side and secondly, this does not (at least not fully) address unforeseen circumstances that can affect raw materials pricing (e.g. disruption supplies due to military conflicts or global pandemic like the COVID-19). ${ }^{5}$ For these reasons entrepreneurs in many cases also seek other ways to address or even eliminate raw material price level insecurity. This can be done through efficient product costing and inventory valuation, but also through contracting with third parties, e.g. insurance companies - by purchasing insurance products - or financial institutions through the acquisition of financial instruments, like derivatives. The situation becomes even more complex for group of companies where a specialized entity engages in hedging prices for the other companies to use the benefits of scale, increase negotiating powers or to cut costs of processing through centralization.

In such cases, due diligence is however required, as the legal construction and contractual setup of price risk management instruments may have a direct impact on their regulatory and tax qualification and in consequence on regulatory and tax obligations of the entrepreneur.

\section{Hedging as A FINANCIAL RISK MANAGEMENT MECHANISM}

As a financial risk management strategy, hedging at the firm level can create value to the benefit of shareholders, in the presence of real-world capital market imperfections, such as direct and indirect costs of financial distress, costly external financing, and taxes. ${ }^{6}$ Economic and legal literature also widely points to high investment opportunities for the company as

${ }^{5}$ See also G.P. Moynihan, M. Ammar Al-Zarrad, Application of Hedging Principles to Materials Price Risk Mitigation in Construction Projects, "International Journal of Construction Engineering and Management” 2015, no. 4(5), p. 181.

${ }^{6}$ A. Butnariu, F.A. Luca, A. Apetrei, Mitigating Financial Risk by Using Hedging Strategies, "SEA - Practical Application of Science" 2018, vol. 6, iss. 16, p. 78. On financial distress reduction as a objective of company level hedge contracts see also J. Graham, D. Rogers, Do Firms Hedge in Response to Tax Incentives?, "Journal of Finance" 57(2), pp. 815-839, https://doi.org/10.1111/1540-6261.00443 
exemplary rationale behind hedging. ${ }^{7}$ The market of derivatives provides for entrepreneurs several alternative products aimed at management of raw material price fluctuation, the most popular of which are forward and future contracts. By way of example, a copper cable producer through concluding a future or forward contract with a financial institution on copper (i.e. by hedging against copper price fluctuation) is able to secure his interests and eliminate risks arising from a contract with a contractor on the basis of which he is obliged to deliver a large quantity of products throughout a long period of time, where all of them are agreed at a up front price. Hedging with the use of forwards or futures can be performed as static or dynamic. In the static variation the entrepreneur may up front determine potential losses or profits within the timeline of the execution of the contract, whereas dynamic hedging consists in the securing from ongoing changes in the price of the base instrument, and its objective is to design the portfolio of base instruments and forwards or futures in such a manner so that the changes in the prices of base instruments be compensated by the changes of the prices of the futures. ${ }^{8}$ In all cases however the idea on which a hedge is performed can be explained on the simple rule "let the loss on the transaction of the base instrument reflect the gain on the transaction on the derivative - and vice versa."

\section{Hedging OF PRICE ELEMENTS IN A DELIVERY OR SALES CONTRACT}

The most simple and common situation where raw material fluctuation is addressed through the conclusion of a hedge contract is where a producer independently decides to conclude such a contract with a financial institution on its own behalf and at its own will and risk. Contractual freedom allows parties to shape an e.g. delivery contract ${ }^{10}$ or a project construction contract (for ease of reference henceforth jointly

${ }^{7}$ G. Allayannis, E. Ofek, Exchange Rate Exposure, Hedging, and the Use of Foreign Currency Derivatives, "Journal of International Money and Finance" 2021, vol. 20, iss. 2, pp. 273-296, https://doi.org/10.1016/S0261-5606(00)00050-4

${ }^{8}$ R. Węgrzyn, Kontrakty terminowe $i$ opcje. Arbitraż, wycena, spekulacja, hedging, Kraków 2019, p. 55. On differences between hedging of forward and future contracts see also M. Bartkowiak, K. Eschaust, Instrumenty pochodne. Wprowadzenie do inżynierii finansowej, Poznań 2019, pp. 66-69, 82-87.

9 T. Nieborak, Pochodne instrumenty finansowe. Aspekty prawnopodatkowe, Warszawa 2004, p. 133.

${ }^{10}$ I.e. a delivery contract within the meaning of art. 605 of the Polish Civil Code. 
as "Sales Contract"), where the price element is at least partially tied with the market price of raw materials on which that product is based (be it copper, aluminium or steel) and impose an obligation on either of the parties to the Sales Contract to perform hedging and acquire a particular derivative. What is more, since raw material prices fluctuate through time and the cooperation between a seller and buyer is most often ongoing, reference to the raw material price in the price of the product may be performed through an ex post price adjustment. Such price adjustment associated with the raw material price may be furthermore based on the performance of a hedge contract concluded by either party (i.e. both the seller as well as the buyer) and take the form of e.g. and ex post settlement periodical reconciliation. As however such reconciliation is often performed ex post, i.e. when the products or services have already been delivered, there remains a practical (i.e. legal and tax) problem how exactly should such reconciliation be qualified, settled and taxed. What is more, due to the fact that an element of the product price is ultimately determined ex post and settled through the process of reconciliation reflecting the performance of a hedge contract concluded by on of the parties, there is risk that such settlement may suggest it being a settlement of a autonomous hedge transaction between both parties. Such interpretation and conclusion should however be qualified as extensive and reaching too far. This is in particular due to the fact that it would require making either of the two following assumptions:

- the Sales Contract is itself a financial derivative contract or

- the parties of the Sales Contract entered into a separate oral hedge contract beyond the Sales Contract.

The first assumption is erroneous due to the fact that it is detached from the full context and subject of the contract which is the sale and delivery of a particular products. The hedging mechanisms are therefore contained not in the contract itself but in independent hedge contract. The Sales Contract in this respect only refers to the results of the hedge (performance of the hedge contract) which are to be reflected in the final price of the product through an ex post price adjustment mechanism. Both the first as well as the second assumption are furthermore groundless also due to the fact that they require additionally assuming that the terms of a relatively complex and specialist derivative transaction are left unregulated or regulated orally. This would be against market standards, in particular the standards od the International Swaps and Derivatives 
Association ("ISDA") 11 and without any reference to the ISDA derivative contract templates without any reference to the wording, mechanisms and content of the actual hedge contracts concluded by either party to the Sales Contract in the first place.

\section{Hedging of PRice elements in a SAles contract}

In light of the regulatory qualification of the hedging reference mechanisms in the Sales Contracts, provisions of law which should be taken into consideration are contained above all in the Polish act on trade in financial instruments ("TFIL") ${ }^{12}$, which is one of the legal acts transposing the MIFID2 ${ }^{13}$ into the Polish legal system. The TFIL regulates the principles, procedures, and conditions for undertaking and conducting operations in the scope of trading in financial instruments, the rights and obligations of entities participating in such trading and supervision performed in this respect by the Polish Commission of Financial Supervision ("KNF"). Then extent in which the actions undertaken by a party to a Sales Contract would therefore involve any form of investment intermediation/brokerage (pl. działalność maklerska) such party would be required to apply for and obtain a KNF license for such activity and become a regulated entity. ${ }^{14}$

The scope of activity qualified as brokerage is defined in art. 69 of the TFIL and covers:

- receiving and transmitting orders to buy or sell financial instruments;

- the execution of orders referred to in item 1, to the account of the principal;

- purchasing or selling financial instruments on its own account;

- managing portfolios that include one or more financial instruments;

11 See e.g. ISDA Legal Guidelines for Smart Derivatives Contracts: Interest Rate Derivatives of February $11^{\text {th }} 2020$, available at https://www.isda.org/a/I7XTE/ISDA-LegalGuidelines-for-Smart-Derivatives-Contracts-IRDs.pdf

12 Polish act of 29 July 2005 on trade in financial instruments (Dz.U. (Polish official journal) 2020, item 89).

13 Directive 2014/65/EU of the European Parliament and of the Council of 15 May 2014 on markets in financial instruments and amending Directive 2002/92/EC and Directive 2011/61/EU.

14 Ustawa o obrocie instrumentami finansowymi, [in:] Prawo rynku kapitałowego. Komentarz, eds M. Wierzbowski, L. Sobolewski, P. Wajda, Warszawa 2018, p. 902. 
- investment advice;

- offering financial instruments;

- rendering of services in performance of concluded underwriting agreements or conclusion and performance of other contracts of a similar nature, if their subject is financial instruments;

- running alternative systems of trade;

- running organized platforms of trade.

It remains beyond doubt that a hedge contract itself can be qualified as a financial instrument within the meaning of art. 2.1 of the TFIL and respectively art. 4.15) of the MIFID2. For this reason, it is necessary to determine whether it is possible to qualify any of the activities performed by Sales Contract parties in relation to it, as brokerage. The majority of the activities constituting brokerage encompass various forms of intermediation of the broker in the process of the conclusion of a financial instrument agreement by one party with the other. This engagement may be in particular direct, where the broker acts in his capacity close to an attorney executing certain legal actions on behalf of a party, taking the form of e.g.:

- receiving and transmitting orders to buy or sell financial instruments;

- execution of orders referred to in item 1), to the account of the principal;

- managing portfolios that include one or more financial instruments;

or indirect, where the broker assists a party in undertaking his investment decision or provides such party with adequate conditions and environment to make some decision, in particular by:

- investment advice;

- offering financial instruments.

In all of the aforementioned scenarios, the broker however always legally acts either on behalf of another party or for the benefit thereof. Despite the fact that a Sales Contract may impose an obligation for one of its parties to acquire a particular derivative and perform hedging, there are no grounds to assume that such an obligation establishes any form of intermediary relationship between them. This is naturally as long as the hedge contract remains an independent legal relationship from the Sales Contract and is entered into independently, without the intermediation of the other party.

Even though a party of a Sales Contract enters into hedge contracts on its own behalf, a hypothetical scenario where it could be considered as engaging in brokerage could occur under art. 69.2.3) of the TFIL. The activity of "purchasing or selling financial instruments on its own account" referred to in art. 69.1.3) of the TFIL is defined in detail in art. 74d of the 
TFIL as "purchase or sale of financial instruments that can be performed using other operations having equivalent effects, in particular for the purpose of acting as the market maker or in order to execute a client order". The legal definition differs therefore from that of art. 4.1.6) of the MIFID2, pursuant to which "dealing on own account' means trading against proprietary capital resulting in the conclusion of transactions in one or more financial instruments". Despite the aforementioned differences in the wording of the definitions, both the TFIL and the MIFID2 clearly make reference to the activity of dealing of financial instruments, i.e. concluding contracts and making purchases with own funds and at own risk of the dealer. It is one of the most traditional trading activities and was developed historically before financial intermediation, fund management or regulated market trade appeared in the form they are known today. Dealing on own account in this respect may be broken down into the simple idea of "buying something on your own behalf at a cheaper price and selling the same thing subsequently at a higher price". ${ }^{15}$ In order therefore for any purchase of financial instruments to be qualified as brokerage it should be performed with the ultimate objective of "selling" to a third party. In case of a derivative financial instrument dealing on own account would amount to a situation where a previously acquired financial instrument is "forwarded" to a third Party. The Sales Contracts could therefore potentially be treated as financial instruments, should they result in one party to the Sales Contract concluding derivative transactions with the other. This is in particular due to the currently wide understanding and definition of derivative contracts in market practice and applicable provisions of law. ${ }^{16}$

15 K. Zacharzewski, Obrót instrumentami finansowymi w reżimie świadczenia usług maklerskich, [in:] System Prawa Handlowego, vol. 4, ed. M. Stec, Warszawa 2016, p. 1198.

16 By way of example Section C.6 of Annex I to the of the MIFID2 qualifies as financial instruments: derivative contracts relating to commodities that must be settled in cash or may be settled in cash at the option of one of the parties other than by reason of default or other termination event and Section C.10 of Annex I to the of the MIFID2 derivative contracts relating to climatic variables, freight rates or inflation rates or other official economic statistics that must be settled in cash or may be settled in cash at the option of one of the parties other than by reason of default or other termination event, as well as any other derivative contracts relating to assets, rights, obligations, indices and measures not otherwise mentioned in this Section, which have the characteristics of other derivative financial instruments, having regard to whether, inter alia, they are traded on a regulated market, OTF, or an MTF. The scope of the definition of furthermore to an even broader in the Commission Delegated Regulation (EU) 2017/565 of 25 April 2016 supplementing 
When a Sales Contract gives rise to a cash settlement by reference to a commodity (raw materials), this at least prima facie may show similarities to the financial instrument definitions of the MIFID2 (especially Section C.6 of Annex I to the of the MIFID2) and the MIFIR. Literal interpretation cannot however be the only one applied to the content of a contract. Art. $65 \$ 1$ of the Polish Civil Code clearly states the principles of interpreting declarations of will in contracts differ in comparison to the principles of interpretation of legal acts, i.e. orders that in relation to the former, primacy be given to the intention of the parties and the purpose of the contract, whereas literal meaning should be analyzed only as the last and final option. ${ }^{17}$ It is clear that in the scenario discussed in this article a contracting party enters into a hedge contracts to address its own business and financial needs, i.e. above all in order to minimize the risks associated with the fluctuation of the prices of the raw materials. The very same objective lays behind the hedge contract performance being used as a product price adjustment mechanism in a Sales Contract. Making a partial reference to the product price which in consequence gives rise to a price adjustment, does not however constitute concluding by the parties of the Sales Contract thereby a derivative financial instrument transaction. For these reasons neither the "purchase of", i.e. entering into a hedge contracts nor the entering into a Sales Contract and its subsequent settlement cannot be qualified as purchasing or selling of financial instruments (dealing) on own account within the meaning of art. 69.2.3) of the TFIL and art. 4.1.6) of the MIFID2.

\section{Hedging of PRICE ELEMENTS IN A SAlES CONTRACT}

- TAX IMPLICATIONS

5.1. Perception of supply as the source of concern

In order to discuss tax implications of hedging we will use production as an example to illustrate how hedging melts into any business process or contract. The remarks used as this example however will be accurate also

Directive 2014/65/EU of the European Parliament and of the Council as regards organisational requirements and operating conditions for investment firms and defined terms for the purposes of that Directive ("MIFIR").

17 See e.g. judgment of the Polish Supreme Court of June $8^{\text {th }} 1999$, II CKN 379/98 along with a approbatory comment of Z. Radwański, OSP 2000, no. 6, item 92; R. Trzaskowski, [in:] Kodeks cywilny. Część ogólna. Komentarz do wybranych przepisów, ed. J. Gudowski, Gdańsk 2018, Art. 65. 
for any other type of supply, further supply of goods or services as long as hedging is part of wider picture and is not intended to be supply of a financial service on a stand alone basis as explained in the first part of this article.

A typical producer in order to deliver goods to its clients will usually need to:

1) design the production process;

2) hire staff;

3) order raw materials;

4) produce goods;

5) provide transportation if applicable.

It is expected that any costs of these actions will be incorporated into the price for which the goods are sold to the customers. Some of those costs will be of fixed nature, whereas some will depend on the number of products to be delivered. The final price is also expected to secure a profit and thus a mark-up will be usually added by the producer.

It is however also market practice not only to calculate the price on the basis of actual costs but also to make sure that these costs (especially variable costs) remain at a certain level. Hedging in finance (costs accounting) is a "trading strategy that leaves one indifferent to market outcomes". 18 This strategy can be achieved through different means, including trading financial instruments such as futures, forwards, options, etc. which will either impact an overall financial position of the producer or specific costs borne by them.

In most cases the producers will choose to enter into hedging contracts with financial institutions namely banks with intention to address fluctuation of their production costs.

The reflection of that strategy that will leave them indifferent to market outcome in many cases will be embedded in a fixed price for the products. In some cases however it is up to the client and producer to decide together on the hedging strategy or even to have the client instruct the producer about the actions to undertake in order to secure the best results.

${ }_{18}$ Hedging, [in:] Encyclopedia of Operations Research and Management Science, eds S.I. Gass, M.C. Fu, Boston 2013, https://doi.org/10.1007/978-1-4419-1153-7_200286 
As mentioned above there is no doubt in terms of hedging cost adjustment treatment in case this is embedded in the price (regardless if the price is fixed or variable). The question however arises in case when there are additional cash flows that are a result of hedging settlement between the producer and their client.

To reflect that impact on the price, specific cash flows must occur. Either from the producer to the client or vice versa. The direction of the flow is a consequence of:

- initial price level,

- final price of raw materials used for production and

- the result of the hedging contract performance and outcome.

If the raw material price goes up, the payment flows from the producer to the client to make sure that the products price remains flat despite higher price of the raw material. If the price of raw materials goes down the cash flow is from the client to the producer to again flatten the final price of the product.

\section{GENERAL REMARKS}

Such cash flows may trigger different qualification from the tax perspective. In this article we focus on value added tax treatment. Below we analyze the following scenarios with the respective argumentation to arrive at the conclusion which of them the best fits a factual and business situation. The reconciliation is thus considered from the VAT perspective as:

- a single supply - a price adjustment mechanism,

- a distinct supply with a further qualification as:

- other service not constituting financial instrument intermediation,

- financial services intermediation (both exempt and taxable as an embedded derivative),

- other cash flows - out of scope of VAT.

The area of concern within the VAT legal framework is whether VAT taxation covers delivery of goods or provision of services within business activity. As per art. 14 section 1 of the Council Directive on the common system of value added tax Directive ("VAT Directive") ${ }^{19}$ 'supply of goods' shall mean the transfer of the right to dispose of tangible property as owner. At the

${ }_{19}$ Council Directive 2006/112/EC 2006/112/EC of 28 November 2006 on the common system of value added tax, Official Journal of the European Union, L 347/1. 
same time, provision of a service is defined as any transaction, which does not constitute a supply of goods (art. 21 section 1 of the VAT Directive). ${ }^{20}$

This dichotomy, though literally unambiguous, is in practice the source of concern when it comes to the tax nature of the supply.

\section{SiNGLE VS. MULTIPLE SUPPLY}

The first concern with respect to taxation is caused by the fact that certain obligations under Sales Contracts may at the first glance comprise of contractual provisions of delivery of products and hedging. Hence, it is important to verify as a first step whether there is a single supply or one can identify multiple supplies under Sales Contract, i.e. if there is a taxable delivery of goods and a supplementary service covering reconciliation stemming from the hedging. This may suggest that there are in fact two separate supplies which would have a different - possibly dichotomic - qualification under VAT. The first obligation towards the purchaser is to deliver products and this raises no doubts. However, the other part of the supply to the purchasers if considered, identified and treated separately will not meet the definition of supply of goods. For this reason, it must be considered as supply of services (potentially even a financial service).

According to CJEU case-law, "where a transaction comprises a bundle of elements and acts, regard must be had to all the circumstances in which the transaction in question takes place in order to determine whether that operation gives rise, for the purposes of VAT, to two or more distinct supplies or to one single supply." ${ }^{21}$

The CJEU has held, first, that it follows from the second subparagraph of art. 1(2) of the VAT Directive that every transaction must normally be regarded as distinct and independent and, secondly, that a transaction which comprises of a single supply from an economic point of view should not be artificially split, so as not to distort the functioning of the VAT system. ${ }^{22}$

20 B. Terra, T. Kajus, Commentary to the VAT Directive, IBFD 2020.

${ }^{21}$ CJEU judgment of 18 October 2018, Volkswagen Financial Services (UK) Ltd, C-153/17, para. 29 and the case-law cited.

22 See the following CJEU judgments: 25 February 1999, Card Protection Plan Ltd (CPP), C-349/96 para. 29; 27 October 2005, Levob Verzekeringen and OV Bank BV, C-41/04, para. 20; 29 march 2007, Aktiebolaget NN, C-111/05, para. 22; 2 December 2010, Everything Everywhere, C-276/09, para. 21 and 22. 
In contrary, there is a single supply where two or more elements or acts supplied by the taxable person to the customer are so closely linked that they form, objectively, a single, indivisible economic supply, which it would be artificial to split. ${ }^{23}$

Therefore, it is crucial to verify if in case of a taxpayer it is possible to identify two separate supplies: (i) the goods and (ii) services or should the whole operation be considered for VAT purposes as a single supply.

The single vs. mixed supply concept is one of the most complex and the purpose of this article is not to provide full background and understanding of this legal and theoretical dilemma in general. However, it is necessary to make some assumptions to further examine this taxation pattern. The comments below will be based on the actual perception of the supply rather than a split into separate phases of the production process. This is due to the fact that even though value added tax has its own approach to look at the reality some problems actually are driven by the fact that VAT is on many occasions too distinct from the reality. Although "Beyond the everyday world... lies the world of VAT; a kind of fiscal theme park in which factual and legal realities are suspended or inverted"24, the real-world perception of a mixed supply shall be then the first stage of the analysis presented below.

\section{CASH FLOWS AS A PRICE ADJUSTMENT MECHANISM}

Analyzing the scope of the taxpayer's contractual performance under a Sales Contract there remains no doubt that elements referred to in pt 1)-5) in Section 4.1 above (such as design, hiring of staff, ordering of raw materials, actual production and transportation of the goods to the buyer) of which the production usually comprises, should jointly be qualified under VAT regime as a delivery of a goods. The final result is actually a product and by all means a split of these steps would be considered artificial. This is regardless of the fact that particular elements of the taxpayer contractual performance technically could be split into separate supplies to the maximum extent as raw material processing and provision

${ }^{23}$ See, to that effect, order of 14 April 2016, Gabarel, C-555/15, para. 44, and judgment of 4 October 2017, Federal Express Europe, C-273/16, para. 37 and 38 and the caselaw cited.

${ }^{24}$ Lord Justice Sedley's decision in Royal \& Sun Alliance v C\&E commissioners (Court of Appeal) 2001. 
of other services. Such split from a practical and business perspective would be nevertheless difficult to reasonably argument and justify. Neither is justified in the "vat fiscal theme park". The question however arises if there are any arguments to state that the parties' intention in case of additional price hedging element was to enter into actually a separate contract, which is simultaneously comprised of a goods delivery and additionally of a delivery of a financial (price hedging) service.

The general obligation that a producer has under Sales Contract is the delivery of products of a certain feature and quality. The purchaser's obligation is to pay the price, which fluctuates due to raw material's price changes being an external factor. This can be secured (flattened out) by hedging either by each transaction party. This remains unaltered even if the price change mechanism due to hedging has been introduced in the contract separately. Hedging in such circumstances should be regarded as a price adjustment the goal of which is to make sure that neither of the parties of a contract faces consequences of unforeseen changes of the price of raw materials not a distinct service as a whole.

In light of the above, a pricing adjustment element, even when explicitly regulated in a contract, should not be interpreted as a separate service. Hedging by either party are in fact raw material price risk management and therefore should be considered as part of the supply of goods. As a consequence, all cash flows between the taxpayer and purchasers without any doubt should be considered as a pure pricing calculation element for the purpose of VAT rather than a separate service. In our opinion there are no reasonable arguments standing behind such conclusion given the economic reality of such traction. The test we would like to propose to apply is if the parties entered into a hedging contract if there was no products' supply agreed. If the test proves negative, there is only one supply of goods under the VAT system.

\section{CASH FlOWS AS A PRICE ADJUSTMENT MECHANISM}

In many cases there is no producer-client contract but instead corporations (group of companies) enter into multi-party contracts where companies belonging to one group are producers and the other group companies are the clientele. In that scenario it is often further the case that any hedging results are settled centrally i.e. via a group treasury entity (one of the 
companies being party to the contract, "Group Treasury Co."). From the supply point of view where a producer delivers goods to their client such Group Treasury Co. is actually a third party as one should expect any contractual relationship being directly between the producer and the client (including any payments from the client to the producer). It raises the complexity of VAT treatment. Therefore, as being used in practice quite often multi-party contracts should be further explored as the cash flows being the final pricing settlements occur with one of the entities being the party to the contract (i.e. Group Treasury Co.). The question arises with respect to the tax treatment in this scenario for any cash flows that are from the Group Treasury Co. and on of the parties belonging to the other group - parties to the multi-party contract.

The answer to that dilemma is actually explicitly provided for by the wording of art. 73 of VAT Directive and has been interpreted by the CJEU in the C-230/87 Naturally Yours ruling.

Article 73 of the VAT Directive establishes the taxable amount for a supply of goods or services. According to this article "the taxable amount shall include everything which constitutes consideration obtained or to be obtained by the supplier, in return for the supply, from the customer or a third party, including subsidies directly linked to the price of the supply". In other words, everything that is qualified as consideration, which typically is captured by the contractual agreements in place, constitutes the taxable basis. ${ }^{25}$

Technically then under 73 also any remuneration received also from a third party should be considered as turnover. However, although such approach is in practice commonly accepted for subsides ${ }^{26}$ explicitly mentioned in fine of art. 73 there is limited jurisprudence in cases where consideration is paid by a commercial third party are considered a taxable basis should they influence the price of products there are doubts for cases other than subsides. ${ }^{27}$

To answer this question a thought must be given to the definition of "consideration". Unfortunately, VAT Directive does not explain further the term, it may seem however that it is a synonym of "taxable amount", which in turn has been defined in art. 79 of VAT Directive. It excludes from the taxable amount price reduction, discounts and rebates but includes cash

${ }^{25}$ CJEU judgment: of 23 November 1988, Naturally Yours, C-230/87 and of 29 July 2010, Astra Zeneca, C-40/09.

${ }^{26}$ CJEU judgment of 6 October 2009, SPO"Landesorganization Kä̈nten, C-267/08.

${ }^{27}$ In our example the third party would be i.e. a treasury center belonging to the producer's group that settles all payables, receivables (including price hedging settlements). 
flows obtained or to be obtained by the supplier no matter the source of such payment. Therefore, the mere fact that the payment has been done by a third party only influences the fact that this should impact the taxable amount, both if it leads to a reduction of the price or its increase.

In this place one must consider if the payment can give a rise to a separate supply of service. This is prima facie excluded as confirmed by multiple CJEU rulings. ${ }^{28}$ The mere fact there is a cash flow between two entities does not give a rise that there is a taxable service as there must be a direct link between the cash flow and the underlying service. Hence firstly it is necessary to identify the service which results in the payment, not vice versa.

Given the above the cash flows including those settled via Group Treasury Co. should be reflected in the turnover reported by the initial producer and their client that have been involved in the goods supply. Technically, under this scenario in order to meet compliance requirements the producer should report in VAT returns turnover changes (+/-) against actual sales of goods against respective client who was delivered the goods.

This approach should lead to changes in invoicing, VAT reporting, Intrastat and EC sales list. It would definitively lead to reporting the final price of the 'widgets' as amended by any hedging. Any cash flows which do not constitute a service should be out of scope of VAT as respective turnover would be reported by the initial parties which undertook the goods' supply.

\section{CASH FLOWS CONSIDERED A DISTINCT SUPPLY - OTHER SERVICE}

Although as presented above we are of the opinion that it is clear that settlement should be interpreted under respective tax laws, below, we present possible other scenarios and arguments against such approach to be used in case of a tax inspection.

Despite the above-presented arguments it is hypothetically possible that one can claim that product price reconciliation should be considered as a supply independent from the sale of the products. The main argument in favor of such interpretation is the existence of separate cash flows occurring after the delivery of the product, i.e. the hedging occurs post-delivery. That argumentation should not however change the VAT consequences described

28 Case C-520/10, Lebara, joined Cases C-53/09 and C-55/09, Loyalty Management and Baxi Group, Case C-270/09, MacDonald Resorts. 
above. A single supply is where one or more elements are to be regarded as constituting the principal supply, while other elements are to be regarded, by contrast, as one or more ancillary supplies which share the tax qualification of the principal supply. In particular, a supply must be regarded as ancillary to a principal supply if it does not constitute for a client a separate transaction in itself but a means of better enjoying the principal service supplied. ${ }^{29}$

The assessment if the transactions can be considered a principal and ancillary supply must be based taking into account the economic objective of that transaction and the interests of the recipients thereof. ${ }^{30}$

Supply of products is a principle supply taxed under VAT as a supply of goods. The product price reconciliation element in contrast allows the purchasers to better enjoy the principal supply. As a result of hedging both parties are in fact secured against raw material price fluctuations. Hedging flattens potential changes of product pricing, which allows for better cost planning. In this regard a hedging transaction as described in this article even if considered a separate service, allows the purchaser to better enjoy the principal supply.

In case where a hedge transaction concluded by the taxpayer is performed by the taxpayer and the cash flow from the purchaser is connected with such a transaction, this fact itself should not be considered as sufficient grounds to qualify as a service rendered by the purchaser to the taxpayer. The cash flows with the purchaser is both factually and contractually connected to the extent that such interpretation would be completely artificial. Thus, a correction invoice or additional invoice reportable should follow.

For any cash flows from the taxpayer to the Group Treasury Co. based on Astra Zeneca and Naturally Yours judgments quoted above the Group Treasury Co. should be considered a supplier of an agency or goods sales intermediation service. The main benefit of Taxpayer is to be able to sale the Products to multiple clients with a single point of contact. Respective invoices should be issued to document the service.

As far as CIT is concerned this approach brings some limited risks. Any charges from the taxpayer would be considered taxable revenue. In turn charges from the Group Treasury Co. are justified as taxable costs allowing actual producer to earn taxable revenues.

${ }^{29}$ CJEU judgment of 18 January 2018, Stadion Amsterdam, C-463/16, EU:C:2018:22, para. 23 and the case-law cited.

30 See, to that effect, CJEU judgment of 8 December 2016, Stock'94, C-208/15, para. 28 and 29 and the case-law cited. 
This scenario can only be considered once one can determine that the hedging of raw materials price constitutes a separate and a distinct service from the supply of products. In this case VAT consequences of such a separate service should be applied.

Intermediation of financial services forms one of the most complex topics under the VAT regime, dating back to more than 50 years ago. When the first directive on VAT was published ${ }^{31}$, financial services were not even included in its scope. It was only until the VI VAT Directive ${ }^{32}$, when a major discussion about financial services taxation took place..$^{33}$ It was raised many times that financial services are specific and therefore need to follow a specific regime which may be different from a typical supply where there is no doubt which party is the supplier and the client. As a result, VAT was doubted to be the appropriate way of taxation. ${ }^{34}$ The reasoning was that first of all that in some financial services it is extremely difficult to identify the service provider and the service recipient where cash flows runs both ways. This is different from a typical service or delivery where the cash flow actually constitutes a consideration - the value of taxable activity. Despite those doubts, the main argument for including financial services in the VAT regime was to make sure that VAT is the most common tax without exception..$^{35}$

The adopted remedy was however to exempt financial services thus hoping the exemption would actually remediate some of the issues or even lower the impact on taxpayers given the difficulties they face (although some disagree stating that the exemption is one of the mysteries of VAT system). ${ }^{36}$

31 First Council Directive 67/227/EEC of 11 April 1967 on the harmonisation of legislation of Member States concerning turnover taxes, Official Journal of the European Communities 1301/67.

32 Sixth Council Directive 77/388/EEC of 17 May 1977 on the harmonization of the laws of the Member States relating to turnover taxes - Common system of value added tax, OJ L 145/77.

${ }^{33}$ G. Hutchings, Les opérations financières et bancaires et la taxe sur la valeur ajoutée, Commission des Communautés Europeénnes. Collection Études. Série Concurrence - Rapprochement des Législations, no. 22, Bruxelles 1973, http://aei.pitt.edu/40281/1/A4676.pdf

${ }^{34}$ Ibidem.

${ }^{35}$ K. Knawa, Metodologia interpretacji przepisów ustawy o podatku od towarów i ustug dotyczacych ustug finansowych. Analiza zakresu przedmiotu oraz podmiotu opodatkowania, "Przegląd Podatkowy" 2018, no. 5, pp. 35-43.

${ }^{36}$ Report on the proposal for a Council directive amending Directive 2006/112/EC on the common system of value added tax, as regards the treatment of insurance and 
The exemption however leads to the inability to recover VAT, which may be a considerable cost despite the fact that VAT should be neutral to businesses which as a matter of principle are taxable activities.

In order to tackle this problem, both the VAT Directive introduced a specific provision base on which financial transactions of an incidental (supportive and auxiliary) nature do not hinder full recovery rights. The taxpayer in such cases must not include in his pro-rata (if applicable) turnover on financial transaction which constitute a supporting service (art. 174(2)b of the VAT Directive).

There are then two questions to consider: (i) was the taxpayer obliged to apply pro-rata rather than a direct allocation of input VAT solely linked to a potentially exempt hedging transaction and if the answer to first question was affirmative, then (ii) was the hedging transaction of an incidental nature and thus not giving a rise to pro-rata anyway.

On answering the first question it is evident that the hedging transactions are related to the main business activity of the taxpayer. It would not be possible for the taxpayer to allocate certain input VAT directly, as there is no separate "business line" where hedging is a separate offering. Thus, pro-rata would be potentially the only option for a taxpayer to allocate input VAT to the potentially exempt hedging transactions.

Given the answer to the first question, it is necessary to conclude in response to the second one that based on the argumentation provided for the "price adjustment" scenario the hedging transaction should be qualified as supporting transactions.

\section{VAT CONSEQUENCES - BOTH EXEMPT AND TAXABLE}

FINANCIAL SERVICE

Even the cash flows stemming from hedging are a financial service it should not lead to immediately considering it VAT exempt. ${ }^{37}$ This is due to the specific exception to the exemption of financial services set forth art. 43 section 16 item 5 of Polish Act on Value Added Tax ("VATA") (the VAT exemption does not apply to derivatives with embedded commodities

financial services (COM(2007)0747 - C6-0473/2007 - 2007/0267(CNS)), Committee on Economic and Monetary Affairs, p. 20, https://www.europarl.europa.eu/sides/getDoc. do?pubRef=-//EP//NONSGML+REPORT+A6-2008-0344+0+DOC+PDF+V0//EN

37 Interpretation of the fiscal Chamber in Katowice of 26 August 2014, IBPP2/443499/14/ICz. 
price reference with actual delivery). There is no doubt that widgets sales is an actual delivery therefore the exemption should not apply.

Still if this approach is overruled by the tax authorities who would claim that despite art. 43 section 16 item 5 of the VATA the exemption should apply then art. 90 section 6 of the VATA should be observed. Under this provision even in case the taxpayer renders exempt services this should not lead to non-irrecoverable VAT as such turnover should be disregarded for the purpose of calculation of input VAT.

There is no doubt that producer's primary business is not financial intermediation, there is also no separate business line where financial services are rendered. Therefore, the payment stemming from the hedging even if considered a financial service should be qualified as of a supportive nature in the meaning of art. 90 section 6 of the VATA). There are no facts stating to the contrary.

This scenario could however be considered as the last preferred option only in case where producer strongly believes that tax compliance burdens here are easier to fulfil and at the same time there are business obstacles for the clients not to accept other scenarios.

If applied this should be consequently reported for any cash flows stemming from hedging as a separate service either by producer or the group entity which settles the hedging results or particular clients who purchased the widgets. ${ }^{38}$

\section{OUT OF SCOPE OF VAT}

If payments resulting from hedging are considered a separate supply one may argue that the cash flows stemming from hedging transactions are considered out of VAT scope. Such approach cannot be justified as the scope of VAT is very wide and includes all activities of sellers, suppliers and producers no matter the outcome of this activity. This is due to the fact that any provision of goods or services by a taxable person acting as such is considered a taxable supply falling under VAT regime.

Hence in order for a certain payment or supply to be considered out of VAT scope it would need to be performed by an entity not within its capacity as a taxpayer. The assessment of acting within the capacity of a taxpayer must however be based on objective factors. Therefore excluding a priori

${ }_{38}$ P. Barnik, E. Kalita, M. Samborski, VAT w sektorze usług finansowych i ubezpieczeniowych, Warszawa 2020. 
hedging transactions out of VAT has no legal grounds neither based on the VAT Directive nor the VATA to be justified.

However, such approach - although not correct - is also presented even in some court rulings. For example, there is a single court ruling in Poland of the Voivodeship Administrative Court in Gorzów Wielkopolski ${ }^{39}$ with very similar conclusions, i.e. where the court in question states that hedging transactions are out of scope of VAT.

The main reasoning behind the judgment was that there is no reciprocity for any cash flows/payments done as a result of a hedge. It was against the fact that the tax authorities were arguing that there is a very broad scope of what constitutes a supply of service in the meaning of the VATA.

\section{TAX COMPLIANCE}

Tax compliance should be a direct consequence on how a transaction is treated from a tax perspective. We are aware of the fact that the presented theoretical where all the cash flows including hedging price adjustment from/to third party (Group Treasury Co.) approach may not be fully applicable in practice given the different approach presented by tax authorities however the purpose of the article is to present the model solution hence the need of presenting the "ideal" approach. Any cash flows from the client to the producer should be considered an increase in price and any cash flow from the taxpayer to the purchaser should without be considered a refund being the result of the final price adjustment followed by respective correction invoices. The same should apply to any cash flows from/to third party (Group Treasury Co.) and regardless the party settling the flows should be reflected in the taxable turnover of the producer who delivers the goods the price of which fluctuates as a result of hedging cash flows.

\section{CONCLUSION}

It is very difficult to capture nature of the hedging transactions in case there are part of a goods delivery process and influence the price. It is even more complex in case of multi-party contracts where the cash flows

39 Ruling of the Voivodeship Administrative Court in Gorzów Wielkopolski of 18 June 2013, I SA/Go 268, http://www.orzeczenia.nsa.gov.pl. The judgment was issued as a result of a tax interpretation. The taxpayer's interpretation was initially considered incorrect by the tax authorities, what was in turn overruled by the Court in the Judgment. 
settlements stemming from the hedging transactions are settled by one of the entities within a group of companies which were not the parties to the initial transaction of the supply of goods. Still from a VAT perspective it is evident those cash flows do not constitute a distinct supply but should be considered an adjustment to the price. The practical difficulty with tax compliance leads however to the conclusion that this option is only viable theoretically. Without changes to the legislation which would clearly define the tax compliance to reflect the price adjustment to the full extent it is not enforceable. Still a theoretical approach is necessary to influence the practice and show the interpretation path to avoid unnecessary distortion of the VAT system that would occur in the incorrect scenario where hedging is considered a distinct supply of financial service that is exempt and thus limiting value of input tax recovery.

\section{BIBLIOGRAPHY}

Allayannis G., Ofek E., Exchange Rate Exposure, Hedging, and the Use of Foreign Currency Derivatives, "Journal of International Money and Finance" 2021, vol. 20, iss. 2, https:// doi.org/10.1016/S0261-5606(00)00050-4

Barnik P., Kalita E., Samborski M., VAT w sektorze ustug finansowych i ubezpieczeniowych, Warszawa 2020.

Bartkowiak M., Eschaust K., Instrumenty pochodne. Wprowadzenie do inżynierii finansowej, Poznań 2019.

Butnariu A., Luca F.-A., Apetrei A., Mitigating Financial Risk by Using Hedging Strategies, "SEA - Practical Application of Science" 2018, vol. 6, iss. 16.

Graham J., Rogers D., Do Firms Hedge in Response to Tax Incentives?, "Journal of Finance" 2002, vol. 57, no. 2, https://doi.org/10.1111/1540-6261.00443

Hedging, [in:] Encyclopedia of Operations Research and Management Science, eds S.I. Gass, M.C. Fu, Boston 2013, https://doi.org/10.1007/978-1-4419-1153-7_200286

Hutchings G., Les opérations financières et bancaires et la taxe sur la valeur ajoutée, Commission des Communautés Europeénnes. Collection Études. Série Concurrence - Rapprochement des Législations, no. 22, Bruxelles 1973, http://aei.pitt.edu/40281/1/A4676.pdf

Kaliński J., Autostrady na Euro 2012, "Kwartalnik Kolegium Ekonomiczno-Społecznego. Studia i Prace" 2013, no. 13, https://doi.org/10.33119/KKESSiP.2013.1.6

Knawa K., Metodologia interpretacji przepisów ustawy o podatku od towarów i ustug dotyczacych ustug finansowych. Analiza zakresu przedmiotu oraz podmiotu opodatkowania, "Przegląd Podatkowy" 2018, no. 5.

Łamasz B., Iwaszczuk N., Ivashchuk O., Selected Methods of Securing the Refining Sector Against Crude Oil Price Fluctuations, "International Journal of Management and Economics" 2018, no. 54(3), https://doi.org/10.2478/ijme-2018-0020 
Moheb-Alizadeh H., Handfield R., The Impact of Raw Materials Price Volatility on Cost of Goods Sold (COGS) for Product Manufacturing, "IEEE Transactions on Engineering Management” 2018, vol. 65, iss. 3, https://doi.org/10.1109/TEM.2018.2796447

Moynihan G.P., Ammar Al-Zarrad M., Application of Hedging Principles to Materials Price Risk Mitigation in Construction Projects, "International Journal of Construction Engineering and Management" 2015, no. 4(5).

Nieborak T., Pochodne instrumenty finansowe. Aspekty prawnopodatkowe, Warszawa 2004. Report on the proposal for a Council directive amending Directive 2006/112/EC on the common system of value added tax, as regards the treatment of insurance and financial services (COM(2007)0747 - C6-0473/2007 - 2007/0267(CNS)), Committee on Economic and Monetary Affairs, https://www.europarl.europa.eu/sides/getDoc. do?pubRef=-//EP//NONSGML+REPORT+A6-2008-0344+0+DOC+PDF+V0//EN

Terra B., Kajus T., Commentary to the VAT Directive, IBFD 2020.

Trzaskowski R., [in:] Kodeks cywilny. Część ogólna. Komentarz do wybranych przepisów. Comment on the art. 65, ed. J. Gudowski, Gdańsk 2018.

Wajda P., Ustawa o obrocie instrumentami finansowymi, [in:] Prawo rynku kapitałowego. Komentarz, eds M. Wierzbowski, L. Sobolewski, P. Wajda, Warszawa 2018.

Węgrzyn R., Kontrakty terminowe i opcje. Arbitraż, wycena, spekulacja, hedging, Kraków 2019. Zacharzewski K., Obrót instrumentami finansowymi w reżimie świadczenia usług maklerskich, [in:] System Prawa Handlowego, vol. 4, ed. M. Stec, Warszawa 2016.

\section{TRANSAKCJE ZABEZPIECZAJĄCE CENĘ (HEDGING) - SKUTKI REGULACYJNE I PODATKOWE}

Streszczenie. Zmienność kosztów ponoszonych w procesie wytwarzania towarów lub usług powoduje, że powszechną praktyką jest zawieranie transakcji zabezpieczających (hedging), których celem jest utrzymanie rentowności transakcji. Rezultat kontraktów terminowych często bywa przedmiotem rozliczeń pomiędzy sprzedawcą a nabywcą.

Celem artykułu jest przedstawienie konsekwencji rozliczeń z tytułu transakcji zabezpieczających na gruncie przepisów regulacyjnych oraz podatkowych. W szczególności w artykule przeanalizowano to, czy rozliczenia z tytułu hedgingu mogą podlegać restrykcjom właściwym dla działalności maklerskiej oraz czy przepływy pieniężne z tego tytułu winny być uznawane za mechanizm korekty ceny, czy też za odrębną transakcję dla celów podatkowych.

Słowa kluczowe: MIFID2, hedging, instrumenty pochodne, podatki, nadzór finansowy 